\title{
Housing conditions and respiratory morbidity in Indigenous children in remote communities in Northwestern Ontario, Canada
}

Thomas Kovesi MD, Gary Mallach MSc, Yoko Schreiber MD, Michael McKay, Gail Lawlor BES, Nick Barrowman PhD, Anne Tsampalieros MD, Ryan Kulka BEng, Ariel Root MSc, Len Kelly MD, Michael Kirlew MD, J. David Miller PhD

Cite as: CMAJ 2022 January 24;194:E80-8. doi: 10.1503/cmaj.202465

\begin{abstract}
Background: Rates of lower respiratory tract infection (LRTI) among First Nations (FN) children living in Canada are elevated. We aimed to quantify indoor environmental quality (IEQ) in the homes of FN children in isolated communities and evaluate any associations with respiratory morbidity.
\end{abstract}

Methods: We performed a crosssectional evaluation of $98 \mathrm{FN}$ children (81 with complete data) aged 3 years or younger, living in $4 \mathrm{FN}$ communities in the Sioux Lookout region of Northern Ontario. We performed medical chart reviews and administered questionnaires. We performed a housing inspection, including quantifying the interior surface area of mould (SAM). We monitored air quality for 5 days in each home and quantified the contaminant loading of settled floor dust, including endotoxin. We analyzed associations between IEQ variables and respiratory conditions using univariable and multivariable analyses.

Results: Participants had a mean age of 1.6 years and $21 \%$ had been admitted to hospital for respiratory infections before age 2 years. Houses were generally crowded (mean occupancy 6.6 [standard deviation 2.6, range 3-17] people per house). Serious housing concerns were frequent, including a lack of functioning controlled ventilation. The mean SAM in the occupied space was $0.2 \mathrm{~m}^{2}$. In multivariable modelling, there was evidence of an association of LRTI with log endotoxin $(p=0.07)$ and age $(p=$ 0.02 ), and for upper respiratory tract infections, with SAM $(p=0.07)$ and age $(p=0.03)$. Wheeze with colds was associated with $\log$ endotoxin $(p=0.03)$ and age $(p=0.04)$.

Interpretation: We observed poor housing conditions and an association between endotoxin and wheezing in young FN children living in Northern Ontario.
Y oung First Nations (FN) children in Canada have high rates of lower respiratory tract infections (LRTIs), including bronchiolitis and pneumonia, with 44 hospital admissions for LRTI per 1000 infants younger than 1 year living in the Sioux Lookout FN Health Authority (SLFNHA) region of northwestern Ontario, compared with 25 per 1000 in the general population, although rates are higher among Inuit infants in Nunavut (235 per 1000).1,2

Adverse respiratory health outcomes have been associated with poor indoor environmental quality (IEQ) worldwide. ${ }^{3,4}$ Surveys have found that more than $24 \%$ of FN and Inuit housing is overcrowded or in need of major repairs or both, compared with $6 \%$ elsewhere in Canada. ${ }^{5}$ Issues related to IEQ are anecdotally reported to be common. ${ }^{6,7}$ Few studies have quantified IEQ in FN housing, and most have focused on road-accessible communities. ${ }^{8-11}$ We evaluated IEQ and respiratory morbidity in the homes of young children in $4 \mathrm{FN}$ communities receiving health services from SLFNHA. Three communities were accessible only by air or winter road. We hypothesized that poor IEQ would be associated with respiratory morbidity in this population.

\section{Methods}

\section{Study design and participants}

We performed a cross-sectional study of IEQ and respiratory morbidity in Lac Seul FN, Kasabonika Lake FN, Sandy Lake FN and Kitchenuhmaykoosib Inninuwug FN. We chose communities based on size (to minimize cost), a variety of rates of LRTI and local recommendations. ${ }^{1}$ We aimed to survey about 25 houses per community. We did not select houses randomly, but given the small population of these communities (about 1200 people per community), our convenience sample included approximately $40 \%$ of eligible houses. ${ }^{12,13}$ 
Protocol-specified inclusion criteria were parental selfidentification as FN and age 3 years or younger. We removed both newborns and children who had recently moved into a house with IEQ measurements from data analysis owing to insufficient IEQ exposure or minimal health outcome data (Figure 1). When there were multiple eligible children in the household, we selected the youngest eligible child, as LRTI is commonest in the first year of life. ${ }^{14}$

\section{Community engagement}

Community selection was guided by SLFNHA. We obtained community support from the SLFNHA Chief's Committee on Health and the leadership of each community - including Chief and Band Council, the Community Health Representative and the Housing Manager - and raised community awareness through local radio phone-in shows. Community groups identified concerns about eczema and skin infections and requested that we evaluate potential associations with IEQ. These findings will be reported separately.

We recruited a community-based research coordinator (typically the Community Health Representative) to help identify eligible houses, administer surveys and provide translation. Study participants received a written report comparing their household measurements to community averages, along with targeted remediation measures. We shared reports with aggregate results

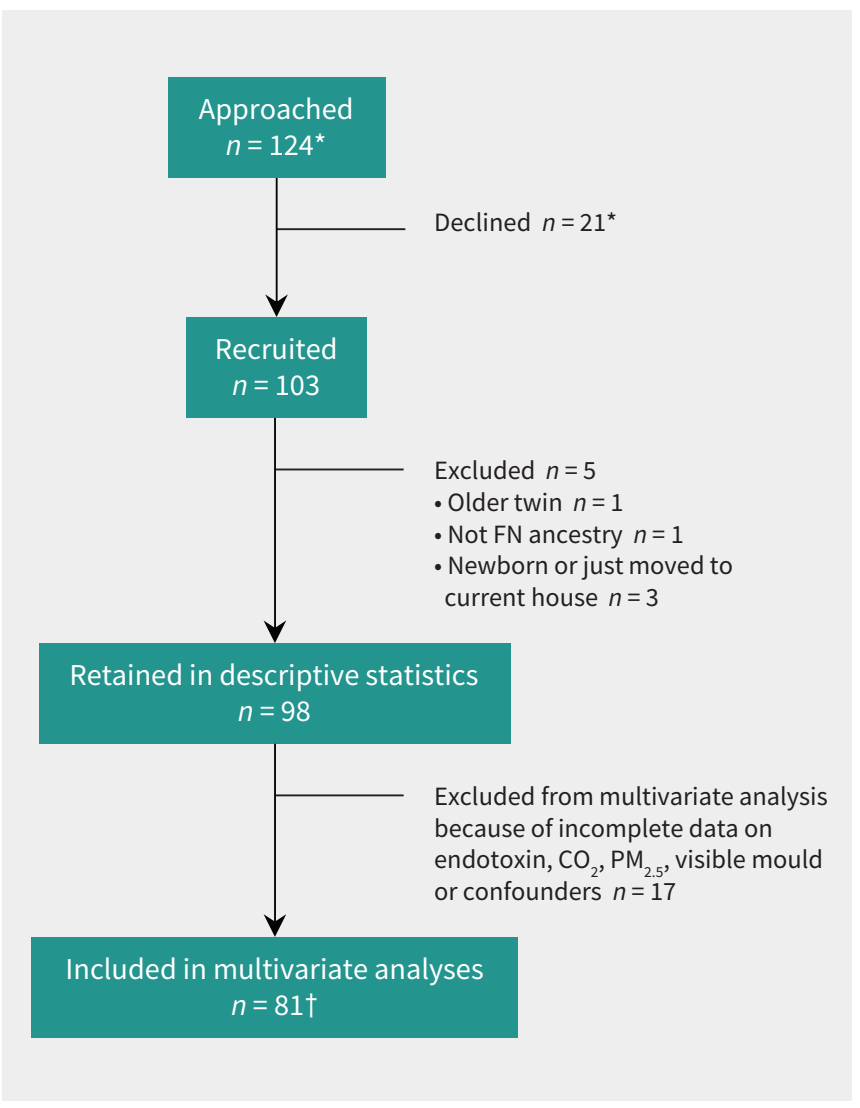

Figure 1: Consolidated Standards of Reporting Trials (CONSORT) flow chart showing flow of participants through the study. Note: $\mathrm{CO}_{2}=$ carbon dioxide, $\mathrm{FN}=$ First Nations, $\mathrm{PM}_{2.5}=$ particulate matter $<2.5 \mu \mathrm{m}$. ${ }^{*}$ Number of participants approached is somewhat approximate for 2 of 4 communities. †Actual sample size depends on each model (see tables). with SLFNHA and the Chief and Council of participating communities. We shared housing issues of immediate safety concern with the local Housing Manager.

\section{Data collection}

The research coordinator administered a validated respiratory health questionnaire. ${ }^{13} \mathrm{~A}$ pediatric respirologist (T.K.) reviewed participant medical health records at community nursing stations for respiratory illness(es).

An indoor air quality specialist and team member documented housing characteristics, including calculation of surface area of visible mould (SAM), using standardized protocols developed in previous Health Canada studies. ${ }^{15,16}$ When crawlspaces could not be safely entered, and there was evidently heavy surface mould contamination, we coded SAM as more than $0.2 \mathrm{~m}^{2}$. We defined presence of overcrowding as more than 1 person per room, excluding bathrooms. ${ }^{5}$

We deployed air monitoring equipment for 3-5 days in the main living area (Appendix 1, available at www.cmaj.ca/lookup/ doi/10.1503/cmaj.202465/tab-related-content). We logged particulate matter $2.5\left(\mathrm{PM}_{2.5}\right)$ concentrations by laser photometry and an in-line filter to collect corresponding gravimetric measurements. We also analyzed filters for levoglucosan, ${ }^{10,17-20}$ a major constituent of wood smoke. ${ }^{21}$ We used a carbon dioxide $\left(\mathrm{CO}_{2}\right)$ sensor attached to a data logger to measure $\mathrm{CO}_{2}$, with a second logger to collect temperature and relative humidity $(\mathrm{RH})$. We also measured these in a central outdoor location in each community. We measured formaldehyde and acetaldehyde with passive samplers and captured volatile organic compounds (VOCs) using thermal desorption tubes.

We collected settled dust samples from the living room floor, typically from 1-2 $\mathrm{m}^{2}$ of flooring. We sieved the dust after storing it in a dry location and analyzed dust fraction $<300 \mu \mathrm{m}$ for endotoxin, house dust mite allergens and 1,3- $\beta$-D-glucan, used as an indicator of fungal load. We extracted and measured the dust mite allergens Der f1 (Dermatophagoides farinae) and Der p1 (D. pteronyssinus). ${ }^{22}$ We calculated glucan and endotoxin load by dividing their weights by the surface area of flooring vacuumed $\left(\mathrm{m}^{2}\right) .{ }^{23,24}$ We carried out IEQ monitoring during the cold weather season when doors and windows are typically closed, and indoor contaminant concentrations are typically highest.

\section{Outcomes}

The primary study outcome was LRTI, and the secondary outcomes were upper respiratory tract infection (URTI) and wheeze with colds (based on questionnaire reporting).

\section{Covariates and variables}

To minimize type I errors and ensure model stability given constraints of sample size, we decided a priori which variables we would use to examine associations between IEQ and health. We chose total SAM and settled dust glucan as markers of mould exposure; $\mathrm{PM}_{2.5}$, indoor $\mathrm{CO}_{2}$ as a proxy of indoor ventilation, and settled dust endotoxin. We included commonly recognized risk factors for LRTI (prematurity and age) in multivariable analyses as potential confounders. ${ }^{25}$ 


\section{Statistical analysis}

Given minimal pre-existing data available on IEQ and pediatric respiratory morbidity in Canadian FN communities, we could not estimate sample size requirements. ${ }^{1}$ Although we had previously observed significant associations between $\mathrm{CO}_{2}$ and LRTI in 49 young Inuit children, LRTI rates are much higher in Nunavut.,1,

We compiled exposure data using SAS, merged them with health and questionnaire data in an Excel spreadsheet and transferred them to $R$ for analyses. ${ }^{26,27}$ We summarized data using means with standard deviations (SDs) as well as medians with interquartile ranges, as several variables were skewed. We described categorical variables using frequencies and percentages. We reported outcomes that were measured during visits as event rates annualized per child's years of life; otherwise, we reported them as a binary (yes or no) outcome. We transformed the covariate endotoxin using the natural logarithm given its skewed distribution. For covariates that were found to have a nonlinear association with an outcome, we included a 3-knot restricted cubic spline in the model. We used multivariable negative binomial regression with an offset given by the log age to model outcomes expressed as event rates (LRTI and URTI). We used multivariable logistic regression to model the outcome of wheeze with colds, which was a binary variable. We included age as a predictor in each of the models. We dichotomized SAM as being above or below $0.2 \mathrm{~m}^{2}{ }^{28}$ Because some values of covariates were missing (Appendix 2, Table S1, available at www.cmaj.ca/lookup/doi/10.1503/cmaj.202465/ tab-related-content), we ran regression modelling using complete cases; we carried out sensitivity analyses using multiple imputation with chained equations and predictive mean matching using the R package MICE with 50 iterations. ${ }^{29}$ Given that about $17 \%$ of records had at least 1 missing value, we used 17 imputations. ${ }^{30}$

\section{Ethics approval}

We obtained Research Ethics Board approvals from Health Canada, the Children's Hospital of Eastern Ontario (CHEO), the Ottawa Hospital, and the Sioux Lookout Meno Ya Win Health Centre. We developed the study under the guidance of the Nishnawbe Aski Nation and SLFNHA. Permission was granted by SLFNHA and each participating community. Although data resided at CHEO, the Nishnawbe Aski Nation had full access to the data, and participated in data analysis and interpretation of results.

\section{Results}

\section{Characteristics of the participants and their housing}

We recruited 103 participants, from 102 houses, into the study. We subsequently excluded 5 participants for protocol violations, leaving 98 participants for descriptive analysis. There were complete data for analyzed covariates for 81 participants, who were included in the multivariable analyses (Figure 1).

Participant and house characteristics are provided in Table 1. The sample size represented about $21 \%$ (98/478) of eligible children. ${ }^{12}$ Participants had a mean age of 1.6 years (SD 1.0; range 0.08-3.91 yr [Table 1]). Fifty-one (52\%) were male. Indoor commercial tobacco smoking was prevalent, with 1 or both guardians smoking in $94 \%$ (88/94) of houses. The median number of smokers per house was 2.0 (range $0-7$ ).

Houses had a mean heated house volume of $243.2 \mathrm{~m}^{3}$ (SD 114.1 ) and most were crowded, with a mean occupancy of 6.6 (SD 2.6, range 3-17) people per house (Table 1 and Table 2). In comparison, the typical volume of a smaller house in southern Canada is $350-400 \mathrm{~m}^{3}$ and $400-600 \mathrm{~m}^{3}$ for a medium-sized house, and the average household size in Canada is 2.5 people. ${ }^{22,31}$ Household concerns identified during the inspections included lack of controlled ventilation with a heat recovery ventilator (HRV) because the device was absent, not working or

\section{Table 1: Characteristics of the houses visited, $n=98$} participants

\begin{tabular}{|c|c|c|}
\hline Exposure variable & $\begin{array}{c}\text { No. }(\%) \text { of } \\
\text { participants* }\end{array}$ & $\begin{array}{c}\text { No. (\%) } \\
\text { of missing } \\
\text { variables }\end{array}$ \\
\hline Location & & $0(0)$ \\
\hline Big Trout Lake & $21(21)$ & \\
\hline Kasabonika & $24(24)$ & \\
\hline Lac Seul & $22(22)$ & \\
\hline Sandy Lake & $31(32)$ & \\
\hline Average heated volume, $\mathrm{m}^{2}$, mean $\pm \mathrm{SD}$ & $243.2 \pm 114.1$ & $0(0)$ \\
\hline No. people in house, mean $\pm S D$ & $6.6 \pm 2.6$ & $0(0)$ \\
\hline Range & $3-17$ & \\
\hline $\begin{array}{l}\text { People/room (excluding bathroom), } \\
\text { mean } \pm \text { SD }\end{array}$ & $1.4 \pm 0.5$ & \\
\hline Crowding (> 1 person/room) & $63(64)$ & \\
\hline Type of heating fuel & & $0(0)$ \\
\hline Wood and electricity & $71(72)$ & \\
\hline Electricity only & $15(15)$ & \\
\hline Other & $12(12)$ & \\
\hline \multicolumn{3}{|l|}{ Guardian smokes } \\
\hline Male & $76(89)$ & $13(13)$ \\
\hline Female & $73(74)$ & $0(0)$ \\
\hline Either & $88(94)$ & $4(4.1)$ \\
\hline Houses lacking potable water & $32(33)$ & $0(0)$ \\
\hline Controlled ventilation fan & $43(44)$ & $1(1)$ \\
\hline Use of fan always or sometimes & $15(16)$ & $2(2)$ \\
\hline Working range hood fan & $52(53)$ & $0(0)$ \\
\hline Range hood fan in bathroom & $44(45)$ & $0(0)$ \\
\hline $\begin{array}{l}\text { Reported an episode of flooding in } \\
\text { home }\end{array}$ & $47(48)$ & $0(0)$ \\
\hline $\begin{array}{l}\text { Signs of water penetration in } \\
\text { exterior walls }\end{array}$ & $43(44)$ & $0(0)$ \\
\hline $\begin{array}{l}\text { Exterior signs of water penetration } \\
\text { in windows }\end{array}$ & $44(45)$ & $0(0)$ \\
\hline
\end{tabular}


not used in $85 \%$ (83/98) of houses; signs of water penetration in exterior walls in 44\% (43/98); immediate safety issues (including extreme fire hazard, electrical hazard or shifting of the house in 6 houses (6\%) (Table 3); and damaged windows (including broken windowpanes and moisture-damaged frames or sills) in 51\% (50/98).

\section{Characteristics of indoor environmental quality}

Characteristics of IEQ variables are provided in Table 2 . The mean living room temperature was $25.6^{\circ} \mathrm{C}$ (SD 2.8), and $\mathrm{RH}$ was $30.0 \%$ (SD 7.9). In contrast, in Saskatoon, Saskatchewan, the mean temperature was $20^{\circ} \mathrm{C}$ and the mean $\mathrm{RH}$ was $35 \%$ in the winter. ${ }^{22}$ The mean indoor $\mathrm{CO}_{2}$ exceeded generally recommended standards (> 1000 ppm) in 56\% (53/95) of the houses (Appendix 3, Supplemental Figure E1, available at www.cmaj.ca/lookup/ doi/10.1503/cmaj.202465/tab-related-content). ${ }^{13,22,32,33}$ Of these, 19 had mean $\mathrm{CO}_{2}$ values between 1500 and $2500 \mathrm{ppm}$. The mean concentration of $\mathrm{PM}_{2.5}$ was 17.1 (SD 18.9) $\mu \mathrm{g} / \mathrm{m}^{3}$, which exceeds World Health Organization 1-year average guidelines for outdoor air of $10 \mu \mathrm{g} / \mathrm{m}^{3,34,35}$ As mean ambient $\mathrm{PM}_{2.5}$ was
4.93 (SD 1.8) $\mu \mathrm{g} / \mathrm{m}^{3}$, indoor $\mathrm{PM}_{2.5}$ appeared to be largely a result of indoor sources such as wood stove use, cooking and commercial tobacco use. Concentrations of VOCs were generally acceptable, although the level of $\mathrm{m}$ - and $\mathrm{p}$-xylene was elevated. ${ }^{3,36-38}$

The mean SAM in the occupied space was $0.2 \mathrm{~m}^{2}$. However, $9 \%(9 / 98)$ of homes had SAM over $1 \%-14 \%$ of the floor area of the occupied space. Six houses had very high SAM $\left(>1 \mathrm{~m}^{2}\right)$ visible below grade (in crawlspaces and basements), which is much greater than reported elsewhere in Canada. ${ }^{39,40}$ The mean load of settled dust endotoxin was 560532 (SD 2264 295) EU/m², which is markedly higher than previously reported in southern Canada. ${ }^{40,41}$ Firewood was stored indoors in most houses, and half $(30 / 60)$ of these had subjectively "moderate or large" amounts of sawdust. Endotoxin levels did not differ substantially by heating source (Table 2). Levoglucosan levels were relatively low. The mean concentration of dust mite allergens Der $\mathrm{p} 1$ and Der f1 were 218.9 (SD 655.8) ng/g and 9.2 (SD 17.9) ng/g, respectively, which were less than that reported in other Canadian houses. ${ }^{42}$

\section{Table 2: Indoor air quality in houses visited, $n=98$ participants}

\begin{tabular}{|c|c|c|c|}
\hline Exposure variable & $\begin{array}{c}\text { No. }(\%) \text { of } \\
\text { missing variables }\end{array}$ & Mean \pm SD & Median (IQR) \\
\hline Relative humidity in child's room & $5(5)$ & $35.0 \pm 9.0$ & $33.5(28.5-43.0)$ \\
\hline Relative humidity in living room & $3(3)$ & $30.0 \pm 7.9$ & $28.1(24.0-36.0)$ \\
\hline Mean living room temperature & $3(3)$ & $25.6 \pm 2.8$ & $25.7(23.6-27.6)$ \\
\hline $\mathrm{CO}_{2}, \mathrm{ppm}$ & $3(3)$ & $1146.0 \pm 505.5$ & $1078.2(845.4-1283.9)$ \\
\hline $\mathrm{Max} \mathrm{CO}_{2}, \mathrm{ppm}$ & $3(3)$ & $1797.1 \pm 708.1$ & $1691.0(1377.5-1948.0)$ \\
\hline Homes with mean $\mathrm{CO}_{2}>1000, n(\%)$ & $3(3)$ & $53 \pm 55.8)$ & \\
\hline Formaldehyde, $\mu \mathrm{g} / \mathrm{m}^{3}$ & $2(2)$ & $19.9 \pm 11.9$ & $18.4(11.4-26.1)$ \\
\hline Acetaldehyde, $\mu \mathrm{g} / \mathrm{m}^{3}$ & $2(2)$ & $18.0 \pm 14.9$ & $15.7(10.2-25.2)$ \\
\hline Glucans, $\mu \mathrm{g} / \mathrm{m}^{2}$ & $8(8)$ & $272.8 \pm 673.7$ & $39.6(14.1-225.3)$ \\
\hline Endotoxin, EU/m² & $8(8)$ & $\begin{array}{l}560532.2 \pm \\
2264294.9\end{array}$ & 35441.4 (12 943.3-144 472.8) \\
\hline \multicolumn{4}{|l|}{ Endotoxin levels in ( $n=71$ homes): } \\
\hline Homes heated by wood and electricity & $5(7)$ & $300558.8 \pm 801266.3$ & 37229.2 (137 96.7-135 025.4) \\
\hline Homes heated by electricity only & $3(20)$ & $\begin{array}{c}2373263.0 \pm \\
5783731.1\end{array}$ & 24222.8 (16 806.6-185 652.9) \\
\hline Homes heated by other heating sources & $0(0)$ & $177655.2 \pm 294689.1$ & 26589.7 (12 191.7-186 518.7) \\
\hline Surface area mould, $\mathrm{m}^{2}$ & $0(0)$ & $0.2 \pm 0.5$ & $0.0(0.0-0.1)$ \\
\hline Levoglucosan, $\mu \mathrm{g} / \mathrm{m}^{3}$ & $15(15)$ & $0.1 \pm 0.3$ & $0.0(0.0-0.1)$ \\
\hline $\mathrm{PM}_{2.5}$ (DustTrak), $\mu \mathrm{g} / \mathrm{m}^{3}$ & $7(7)$ & $66.8 \pm 85.3$ & $40.5(26.3-74.9)$ \\
\hline $\mathrm{PM}_{2.5}$ gravimetric, $\mu \mathrm{g} / \mathrm{m}^{3}$ & $11(11)$ & $17.1 \pm 18.9$ & $11.7(6.8-19.2)$ \\
\hline Ultrafine particulate matter, count $/ \mathrm{cm}^{3}$ & $13(13)$ & $31035.3 \pm 19399.5$ & 25797.0 (16 924.9-38 535.1) \\
\hline Benzene, $\mu \mathrm{g} / \mathrm{m}^{3}$ & $4(4)$ & $2.2 \pm 1.8$ & $1.6(0.9-3.1)$ \\
\hline Toluene, $\mu \mathrm{g} / \mathrm{m}^{3}$ & $4(4)$ & $7.8 \pm 10.5$ & $3.9(2.4-8.8)$ \\
\hline$m$-xylene $+p$-xylene concentration, $\mu \mathrm{g} / \mathrm{m}^{3}$ & $4(4)$ & $6.3 \pm 18.2$ & $2.3(1.3-5.2)$ \\
\hline Nicotine + nicotyrine concentration, $\mu \mathrm{g} / \mathrm{m}^{3}$ & $4(4)$ & $0.6 \pm 1.4$ & $0.0(0.0-0.5)$ \\
\hline
\end{tabular}




\section{Respiratory diseases}

Lower respiratory tract infections were frequent, with a mean of 0.73 (SD 1.45) LRTIs per year of life. Of participants, $21 \%$ (20/97) were admitted to hospital in the first 2 years of life and 25\% (24/98) were medically evacuated for a respiratory illness. Children were seen in the health centre with URTIs an average of 1.6 (SD 1.8) times per year of life. Wheezing with colds occurred in more than one-third $(39 \%, 38 / 98)$, but only $4 / 98$ of children (4\%) received a diagnosis of asthma.

Table 3: Major housing issues identified by the indoor air quality specialist

\begin{tabular}{|c|c|c|}
\hline $\begin{array}{l}\text { Type of } \\
\text { issue }\end{array}$ & $\begin{array}{c}\text { No. }(\%) \text { of } \\
\text { houses affected } \\
n=98\end{array}$ & Description \\
\hline \multicolumn{3}{|c|}{ Immediate safety } \\
\hline & $1(1)$ & $\begin{array}{l}\text { No wood stove chimney shield } \\
\text { (extreme fire hazard) }\end{array}$ \\
\hline & $1(1)$ & $\begin{array}{l}\text { No insulation baffle around chimney } \\
\text { in attic: fire hazard }\end{array}$ \\
\hline & $2(2)$ & Electrical fire or shock hazard \\
\hline & $1(1)$ & $\begin{array}{l}\text { House shifted; many large gaps with } \\
\text { rotten wood }\end{array}$ \\
\hline & $1(1)$ & $\begin{array}{l}\text { Possible cracked heat exchanger in } \\
\text { wood stove; house contaminated } \\
\text { with soot and carbon monoxide risk } \\
\text { if furnace blower turned off }\end{array}$ \\
\hline \multicolumn{3}{|c|}{ Water penetration (and plumbing) } \\
\hline & $13(13)$ & $\begin{array}{l}\text { Plumbing fixture leaks with area } \\
\text { dampness (bathroom, kitchen, } \\
\text { water tank) }\end{array}$ \\
\hline & $13(13)$ & $\begin{array}{l}\text { Mouldy or damp crawlspace floor (in } \\
\text { most cases, polyurethane sheet } \\
\text { vapour barrier over dirt floor missing) }\end{array}$ \\
\hline & $10(10)$ & $\begin{array}{l}\text { Sump pump not working, not } \\
\text { present or drains too close to } \\
\text { foundation }\end{array}$ \\
\hline & $4(4)$ & $\begin{array}{l}\text { Sump pump discharge pipe not } \\
\text { connected }\end{array}$ \\
\hline & $6(6)$ & $\begin{array}{l}\text { Roof leaks with mould or damage to } \\
\text { ceilings, walls }\end{array}$ \\
\hline & $4(4)$ & $\begin{array}{l}\text { Exterior damage leading to water } \\
\text { penetration }\end{array}$ \\
\hline & $3(3)$ & $\begin{array}{l}\text { Broken chimney flashing - chimney } \\
\text { leaks when it rains }\end{array}$ \\
\hline & $3(3)$ & Plumbing not working \\
\hline \multicolumn{3}{|c|}{ Air quality or ventilation } \\
\hline & $2(2)$ & Exhaust fans vent into attic \\
\hline & $1(1)$ & $\begin{array}{l}\text { Heat recovery ventilator fresh air } \\
\text { intake near oil furnace exhaust }\end{array}$ \\
\hline & $1(1)$ & $\begin{array}{l}\text { No openable windows, no exhaust } \\
\text { fans and no heat recovery ventilator }\end{array}$ \\
\hline & $1(1)$ & Oil furnace back drafting \\
\hline & $1(1)$ & Wood stove back drafting \\
\hline
\end{tabular}

Multivariable modelling for primary outcome of lower respiratory tract infection

In a multivariable model with complete cases, there was evidence of an association between log endotoxin and the rate of LRTIs that approached conventional statistical significance (adjusted rate ratio [RR] 1.14 per unit of $\log \left[\mathrm{EU} / \mathrm{m}^{2}\right], 95 \%$ confidence interval $[\mathrm{Cl}]$ 0.98-1.33), and age and the rate of LRTIs (adjusted RR 0.65 per year of life, $95 \% \mathrm{Cl} 0.46-0.91$ ) (Table 4). Results were similar using the imputed data set (Appendix 2, Supplementary Table S2).

\section{Multivariable modelling for secondary respiratory outcomes (upper respiratory tract infections and wheeze with a cold)}

In a multivariable model using complete cases, there was evidence for an association between SAM $>0.2 \mathrm{~m}^{2}$ and rates of URTI that approached conventional statistical significance (adjusted RR $1.61,95 \% \mathrm{Cl} 0.95-2.72$ ), as well as age and rate of URTI (adjusted RR 0.79 per year of life, 95\% Cl 0.65-0.98) (Table 5 and Appendix 2, Supplementary Table S3). In a multivariable model of complete cases with wheeze with colds as the outcome, log endotoxin was associated with wheeze with colds (odds ratio [OR] 1.32 per unit of $\left.\log \left[\mathrm{EU} / \mathrm{m}^{2}\right], 95 \% \mathrm{Cl} 1.04-1.70\right)$ and with age (OR 1.70 per year, 95\% Cl 1.03-2.90) (Table 6). These effects were slightly attenuated using imputed data in the model (Appendix 2, Supplementary Table S4).

\section{Interpretation}

This quantitative assessment confirmed previous surveys that reported that many FN houses require major repair(s). ${ }^{5}$ The housing crisis experienced by FN people in Canada is historically well documented..$^{8,43,44}$ Centuries of assimilation tactics, colonialism and systemic racism have created structural barriers including employment, education, economic and housing inadequacies, as well as systematically disrupting transfer of intergenerational life skills. Inequalities and underfunding have resulted in houses that are poorly constructed and of insufficient size, with inadequate funding for maintenance and upkeep. With the loss of integrity of the air and vapour barrier, overcrowding, inadequate ventilation and indoor storage of firewood, contamination with mould and endotoxin was common, with high interior SAM and extraordinarily elevated endotoxin loading. Endotoxin exposure was associated with wheeze with colds and tended to be associated with LRTI, whereas SAM tended to be associated with URTI visits.

Endotoxin is a cell wall component of gram-negative bacteria. ${ }^{45,46}$ The mean load of settled dust endotoxin in study homes was much higher than in American homes in general (17600 EU/ $\left.\mathrm{m}^{2}\right) .{ }^{23}$ Settled dust endotoxin has previously been associated with wheezing in young children, ${ }^{47,48}$ and airborne endotoxin with acute respiratory illnesses and infections in infants. ${ }^{45}$ Endotoxin has complex effects on immune function, with early exposure reducing the incidence of asthma, and late exposure increasing the risk of exacerbations in people with pre-existing asthma. ${ }^{46,47}$ The high prevalence of wheeze with colds suggests asthma may be underdiagnosed, although the term "wheezing" may have been used 
Table 4: Multivariable modelling for LRTI (complete case analysis, $n=81$, with 74 LRTI visits)*

\begin{tabular}{|c|c|c|}
\hline Covariate & $\begin{array}{l}\text { Unadjusted rate ratio } \\
\qquad(95 \% \mathrm{Cl})\end{array}$ & $\begin{array}{c}\text { Adjusted rate ratio } \\
\qquad(95 \% \mathrm{Cl})\end{array}$ \\
\hline Age, yr & $0.62(0.45-0.86)$ & $0.65(0.46-0.91)$ \\
\hline Born premature, yes & $1.68(0.73-3.98)$ & $1.57(0.76-3.24)$ \\
\hline $\mathrm{PM}_{2.5}, \mu \mathrm{g} / \mathrm{m}^{3}$ & $0.999(0.994-1.005)$ & $1.00(0.99-1.00)$ \\
\hline Surface area mould $>0.2 \mathrm{~m}^{2}$, yes & $0.33(0.10-0.99)$ & $0.44(0.14-1.20)$ \\
\hline Log endotoxin, EU/m² & $1.14(0.96-1.36)$ & $1.14(0.98-1.33)$ \\
\hline \multicolumn{3}{|c|}{$\mathrm{CO}_{2}$ (3-knot restricted cubic splinet), ppm } \\
\hline First coefficient & $1.003(1.000-1.005)$ & $1.001(0.999-1.003)$ \\
\hline Second coefficient & $0.996(0.992-0.999)$ & $0.998(0.994-1.001)$ \\
\hline \multicolumn{3}{|c|}{$\begin{array}{l}\text { Note: } \mathrm{Cl}=\text { confidence interval, } \mathrm{CO}_{2}=\text { carbon dioxide, } \mathrm{LRTI}=\text { lower respiratory tract infection, } \mathrm{PM}_{25}=\text { particulate } \text { matter }<2.5 \mu \mathrm{m}, \mathrm{ppm}=\text { parts per } \\
\text { million. } \\
{ }^{*} \text { Rate ratios represent estimated ratio of events/year of life between groups. Rate ratios are per-unit increase for continuous variables or for the } \\
\text { described group (e.g., surface area }>0.2 \mathrm{~m}^{2} \text { or born premature) compared with the referent. An adjusted rate ratio }>1 \text { indicates the covariate is } \\
\text { associated with increased event rates. } \\
\text { †Knots for } \mathrm{CO}_{2}: 600.1,1054.2,1865.1 .\end{array}$} \\
\hline
\end{tabular}

\section{Table 5: Multivariable modelling for URTI (complete case analysis, $n=81$, with 189 URTI visits)*}

\begin{tabular}{|c|c|c|}
\hline Covariate & $\begin{array}{c}\text { Unadjusted rate ratio } \\
\qquad(95 \% \mathrm{Cl})\end{array}$ & $\begin{array}{c}\text { Adjusted rate ratio } \\
(95 \% \mathrm{Cl})\end{array}$ \\
\hline Age, yr & $0.79(0.64-0.97)$ & $0.79(0.65-0.98)$ \\
\hline Born premature, yes & $0.93(0.55-1.58)$ & $0.89(0.53-1.48)$ \\
\hline $\mathrm{PM}_{2.5}, \mathrm{\mu g} / \mathrm{m}^{3}$ & $1.001(0.997-1.004)$ & $1.000(0.997-1.003)$ \\
\hline Surface area of mould $>0.2 \mathrm{~m}^{2}$, yes & $1.65(0.96-2.88)$ & $1.61(0.95-2.72)$ \\
\hline $\mathrm{CO}_{2}, \mathrm{ppm}$ & $1.000(1.000-1.001)$ & $1.000(1.000-1.001)$ \\
\hline \multicolumn{3}{|c|}{ Log endotoxin (3-knot restricted cubic spline†), EU/m² } \\
\hline First coefficient & $1.28(0.96-1.72)$ & $1.21(0.90-1.64)$ \\
\hline Second coefficient & $0.73(0.51-1.03)$ & $0.780 .54-1.11)$ \\
\hline \multicolumn{3}{|c|}{$\begin{array}{l}\text { Note: } \mathrm{Cl}=\text { confidence interval, } \mathrm{CO}_{2}=\text { carbon dioxide, } \mathrm{PM}_{25}=\text { particulate matter }<2.5 \mu \mathrm{m}, \mathrm{URTI}=\text { upper respiratory tract infection. } \\
{ }^{*} \text { Rate ratios represent estimated ratio of events/year of life between groups. Rate ratios are per-unit increase for continuous variables or for the } \\
\text { described group (e.g., surface area }>0.2 \mathrm{~m}^{2} \text { or born premature) compared with the referent. An adjusted rate ratio }>1 \text { indicates the covariate is } \\
\text { associated with increased event rates. } \\
\text { †Knots for log endotoxin: } 7.95,10.50,14.71 \text {. }\end{array}$} \\
\hline
\end{tabular}

\section{Table 6: Multivariable modelling for wheeze with cold (complete case analysis, $n=81$, with 31 participants reporting wheeze with cold)*}

\begin{tabular}{|c|c|c|}
\hline Covariate & $\begin{array}{l}\text { Unadjusted odds ratio } \\
\qquad(95 \% \mathrm{Cl})\end{array}$ & $\begin{array}{l}\text { Adjusted odds ratio } \\
\qquad(95 \% \mathrm{Cl})\end{array}$ \\
\hline Age, yr & $1.75(1.10-2.86)$ & $1.70(1.03-2.90)$ \\
\hline Born premature, yes & $1.33(0.43-4.03)$ & $1.09(0.32-3.62)$ \\
\hline $\mathrm{PM}_{2.5}, \mu \mathrm{g} / \mathrm{m}^{3}$ & $0.997(0.997-1.003)$ & $0.998(0.989-1.004)$ \\
\hline Surface area of mould $>0.2 \mathrm{~m}^{2}$, yes & $1.01(0.28-3.36)$ & $0.82(0.20-3.02)$ \\
\hline $\mathrm{CO}_{2}, \mathrm{ppm}$ & $1.000(0.999-1.001)$ & $1.000(0.998-1.001)$ \\
\hline Log endotoxin, $\mathrm{EU} / \mathrm{m}^{2}$ & $1.33(1.06-1.72)$ & $1.32(1.04-1.70)$ \\
\hline
\end{tabular}


imprecisely. ${ }^{49}$ Endotoxin levels were likely increased by indoor storage and use of firewood and accumulation of sawdust. ${ }^{50}$

Many houses were poorly situated, leaving them prone to flooding and water penetration. Wet and mouldy crawlspaces were common. Mean 1,3- $\beta$-D-glucan loading in study houses was much higher than in infants' houses in Cincinnati $\left(18.4 \mu \mathrm{g} / \mathrm{m}^{2}\right) .{ }^{51}$ Surface area of visible mould tended to be associated with URTIs, which may be clinically important as URTIs are important antecedents for more severe respiratory illnesses, including LRTI and asthma exacerbations..$^{52,53}$ Surface area of visible mould above $0.2 \mathrm{~m}^{2}$ has been associated with recurrent wheezing in American infants, with a relative risk of 2.1. ${ }^{28}$ Previous surveys have described a high prevalence of visible mould in FN homes. ${ }^{11,54}$ Education on the need to notify housing departments about water leaks and flooding is essential, but must be accompanied by funding to effect repairs.

Other important IEQ concerns were frequent. Crowding resembled previous observations in Nunavut, where it was associated with wheezing with colds. ${ }^{22}$ Crowding increases the risk of viral infections and airborne contaminants. ${ }^{55}$ Mean indoor $\mathrm{CO}_{2}$, as a reflection of adequacy of ventilation, was similar to that in Manitoba FN communities (1174 ppm), ${ }^{10}$ but was somewhat less than in Nunavut (1358 ppm). ${ }^{13}$ Only 44\% of study houses had an HRV, and less than $15 \%$ had an operational one. Similarly, $57.8 \%-87.5 \%$ of FN houses in northern Manitoba had no or a nonfunctional HRV. ${ }^{11}$ The lack of substantial associations between $\mathrm{CO}_{2}$ or other IEQ factors and LRTI may reflect a lower risk of LRTI than that observed in Inuit children and children in low-income countries. ${ }^{56,57}$ Indoor $\mathrm{PM}_{2.5}$ concentrations in our study were not unusual for homes heated by woodstoves. ${ }^{58,59}$ Levoglucosan is primarily a marker of wood combustion. ${ }^{21,59,60}$ The indoor levoglucosan/PM 2.5 ratio of $0.13 \%$ (SD 0.31) was less in rural British Columbia (1.0\%), ${ }^{60}$ suggesting a higher contribution of commercial tobacco smoke. Commercial tobacco smoke exposure is a known risk factor for LRTI, ${ }^{61}$ but the lack of unexposed children precluded meaningful analysis. ${ }^{22,55}$ Elevated indoor concentrations of $\mathrm{PM}_{2.5}$ have been associated with LRTI elswhere..$^{58,62,63}$ Some IEQ problems might be rectifiable by residents with relevant educational tools related to HRV use, firewood storage and furniture placement to promote air circulation, and reduce moisture accumulation and mould growth. Often, this will require addressing systemic, structural and economic barriers faced by residents. ${ }^{64}$

Our study had the benefit of engaging an indoor air quality specialist, who used standardized tools and quantitative methods. We had broad community support and obtained direction from the SLFNHA Chief's Committee on Health. Given our preliminary results, we supported capacity building by working with FN students to develop educational deliverables and by developing HRV educational programs for housing departments. ${ }^{65}$

\section{Limitations}

Our study had limitations common to most studies of IEQ: the cross-sectional design and disparity between the time of IEQ measurements and historical outcomes means that only associations, rather than causality, can be surmised. ${ }^{13,24,28}$ Precision and power were limited owing to the small sample size. The larger proportion of eligible children who were included, compared with typ- ical urban research, enhanced generalizability, although lack of random sampling increased the risk of selection bias. Because we assessed several exposures and outcomes, there may be an increased risk of type I errors. Flooring settled dust mite is often used as a proxy for indoor burden of dust mite antigen, but less dust could be collected as most houses were not carpeted. ${ }^{66}$ We therefore also sometimes collected dust from upholstered furniture, which has been done elsewhere, but is less well standardized. ${ }^{23,67}$ The 2 methods for quantifying $\mathrm{PM}_{2.5}$ - gravimetric and photometric - are not completely comparable, limiting comparison with other studies. Variable quantification methods for endotoxin also hampers comparison between studies. ${ }^{24}$ Further research is needed to determine how best to use levoglucosan as a marker of indoor wood combustion. ${ }^{59}$ The best method of quantifying indoor mould is controversial, particularly in houses where much of the mould is located outside the lived space, such as crawlspaces, but from where it can potentially infiltrate. ${ }^{4,68,69}$ We did not record how many households were approached for the study but declined participation, although we believe we have a close estimate of the number of households that declined.

\section{Conclusion}

Many houses in these FN communities had substantial IEQ problems. Presence of endotoxin was associated with wheezing with colds and tended to be associated with LRTI in young children. Surface area of visible mould tended to be associated with URTI visits. Urgent collective action is needed to respond to historically damaging impacts of colonization, including systemic indifference. ${ }^{70}$ Increased housing stock appropriate for local geographic, climatic and cultural needs should be matched to solutions that are FN led and governed. Economic opportunity, elimination of food insecurity and provision of potable water will allow communities and residents to apply more resources to the upkeep of existing houses. Such measures will improve the overall health of FN peoples, particularly vulnerable family members, such as children and elders. ${ }^{71,72}$

\section{References}

1. McCuskee S, Kirlew M, Kelly L, et al. Bronchiolitis and pneumonia requiring hospitalization in young first nations children in Northern Ontario, Canada. Pediatr Infect Dis J 2014;33:1023-6.

2. Banerji A, Panzov V, Young M, et al. Hospital admissions for lower respiratory tract infections among infants in the Canadian Arctic: a cohort study. CMAJ Open 2016;4:E615-22.

3. Mendell MJ. Indoor residential chemical emissions as risk factors for respiratory and allergic effects in children: a review. Indoor Air 2007;17:259-77.

4. Mendell MJ, Mirer AG, Cheung K, et al. Respiratory and allergic health effects of dampness, mold, and dampness-related agents: a review of the epidemiologic evidence. Environ Health Perspect 2011;119:748-56.

5. The housing conditions of Aboriginal people in Canada. Census in Brief. Ottawa: Statistics Canada; 2017, modified 2019 Apr. 3. Available: https://www12.statcan. gc.ca/census-recensement/2016/as-sa/98-200-x/2016021/98-200-x2016021-eng. cfm (accessed 2020 May 10).

6. Elash A. 'Nothing has been done' to save remote First Nation from mould, leaders complain. CBC News Indigenous 2019 Feb. 15. Available: https://www. cbc.ca/news/indigenous/nothing-has-been-done-to-save-remote-first-nation -from-mould-leaders-complain-1.5022214 (accessed 2021 Feb. 28).

7. Nunavut MP on housing tour describes mould-infested homes and furniture freezing to walls. CBC Radio As It Happens 2020 Aug. 26. Available: https:// www.cbc.ca/radio/asithappens/as-it-happens-wednesday-edition-1.5700583/ nunavut-mp-on-housing-tour-describes-mould-infested-homes-and-furniture -freezing-to-walls-1.5700594 (accessed 2021 Feb. 28). 
8. Optis M, Shaw K, Stephenson P, et al. Mold growth in on-reserve homes in Canada: the need for research, education, policy, and funding. J Environ Health 2012;74:14-21.

9. Berghout J, Miller JD, Mazerolle R, et al. Indoor environmental quality in homes of asthmatic children on the Elsipogtog Reserve (NB), Canada. Int J Circumpolar Health 2005;64:77-85.

10. Weichenthal S, Mallach G, Kulka R, et al. A randomized double-blind crossover study of indoor air filtration and acute changes in cardiorespiratory health in a First Nations community. Indoor Air 2013;23:175-84.

11. Larcombe L, Nickerson P, Singer M, et al. Housing conditions in 2 Canadian First Nations communities. Int J Circumpolar Health 2011;70:141-53.

12. Aboriginal Population Profile, 2016 Census: Sandy Lake First Nation [First Nation/Indian band or Tribal Council area], Ontario [table]. Ottawa: Statistics Canada; modified 2019 June 19. Available: https://www12.statcan.gc.ca/census -recensement/2016/dp-pd/abpopprof/infogrph/infgrph.cfm?LANG=E\&DGUID= 2016C1005246\&PR=35 (accessed 2022 Jan. 5)

13. Kovesi T, Gilbert NL, Stocco C, et al. Indoor air quality and the risk of lower respiratory tract infections in young Canadian Inuit children. CMAJ 2007;177:155-60.

14. Kovesi TA, Cao Z, Osborne G, et al. Severe early lower respiratory tract infection is associated with subsequent respiratory morbidity in preschool Inuit children in Nunavut, Canada. J Asthma 2011;48:241-7.

15. Foto M, Vrijmoed LLP, Miller JD, et al. A comparison of airborne ergosterol, glucan and Air-O-Cell data in relation to physical assessments of mold damage and some other parameters. Indoor Air 2005;15:257-66.

16. Recognition, evaluation, and control of indoor mold. 2nd ed. Falls Church (VA): American Industrial Hygiene Association; 2008.

17. Weichenthal S, Kulka R, Lavigne E, et al. Biomass Burning as a Source of Ambient Fine Particulate Air Pollution and Acute Myocardial Infarction. Epidemiology 2017;28:329-37.

18. Yu L, Wang B, Cheng M, et al. Association between indoor formaldehyde exposure and asthma: A systematic review and meta-analysis of observational studies. Indoor Air 2020;30:682-90.

19. Hulin M, Caillaud D, Annesi-Maesano I. Indoor air pollution and childhood asthma: variations between urban and rural areas. Indoor Air 2010;20:502-14.

20. Bolden AL, Kwiatkowski CF, Colborn T. New look at BTEX: Are ambient levels a problem? Environ Sci Technol 2015;49:5261-76.

21. Allen RLS, Millar G, Brauer M. The impact of wood stove technology upgrades on indoor residential air quality. Atmos Environ 2009;43:5908-15.

22. Kovesi T, Creery D, Gilbert NL, et al. Indoor air quality risk factors for severe lower respiratory tract infections in Inuit infants in Baffin Region, Nunavut: a pilot study. Indoor Air 2006;16:266-75.

23. Thorne PS, Kulhánková K, Yin M, et al. Endotoxin exposure is a risk factor for asthma: the national survey of endotoxin in United States housing. Am J Respir Crit Care Med 2005;172:1371-7.

24. Gehring U, Strikwold M, Schram-Bijkerk D, et al. Asthma and allergic symptoms in relation to house dust endotoxin: Phase Two of the International Study on Asthma and Allergies in Childhood (ISAAC II). Clin Exp Allergy 2008;38:1911-20.

25. Law BJ, Carbonell-Estrany X, Simoes EAF. An update on respiratory syncytial virus epidemiology: a developed country perspective. Respir Med 2002;96(Suppl B):S1-7.

26. Wheeler AJ, Xu X, Kulka R, et al. Windsor, Ontario exposure assessment study: design and methods validation of personal, indoor, and outdoor air pollution monitoring. J Air Waste Manag Assoc 2011;61:324-38.

27. R Core Team. R: a language and environment for statistical computing. Vienna (Austria): R Foundation for Statistical Computing; 2019.

28. Cho SH, Reponen T, LeMasters G, et al. Mold damage in homes and wheezing in infants. Ann Allergy Asthma Immunol 2006;97:539-45.

29. van Buuren S, Groothuis-Oudshoorn K. mice: multivariate imputation by chained equations in R. J Stat Softw 2011;45:1-67.

30. White IR, Royston P, Wood AM. Multiple imputation using chained equations: issues and guidance for practice. Stat Med 2011;30:377-99.

31. Appendix G: Estimated number of households and average household size by domain, Canada. Ottawa: Statistics Canada; 2017. Available: https://www150.statcan. gc.ca/n1/pub/62f0026m/2017002/app-ann-g-eng.htm (accessed 2021 Feb. 28).

32. Persily A, Polidoro BJ. Residential application of an indoor carbon dioxide metric. Proceedings of the 40th AIVC - 8th TightVent - 6th venticool Conference; 2019 Oct. 15-16; Ghent (Belgium).

33. Consultation: proposed residential indoor air quality guidelines for carbon dioxide. Ottawa: Health Canada; 2020. Available: https://www.canada.ca/ en/health-canada/programs/consultation-residential-indoor-air-quality -guidelines-carbon-dioxide/document.html (accessed 2021 Feb. 28).
34. Singleton R, Salkoski AJ, Bulkow L, et al. Housing characteristics and indoor air quality in households of Alaska Native children with chronic lung conditions. Indoor Air 2017;27:478-86.

35. Kearney J, Wallace L, MacNeill M, et al. Residential indoor and outdoor ultrafine particles in Windsor, Ontario. Atmos Environ 2011;45:7583-93.

36. Delfino RJ, Gong H, Linn WS, et al. Respiratory symptoms and peak expiratory flow in children with asthma in relation to volatile organic compounds in exhaled breath and ambient air. J Expo Anal Environ Epidemiol 2003;13:348-63.

37. Residential indoor air quality guidelines. Ottawa: Health Canada; $2021 \mathrm{Nov}$. 25. Available: https://www.canada.ca/en/health-canada/services/air-quality/ residential-indoor-air-quality-guidelines.html (accessed 2021 Feb. 28).

38. Kraev TA, Adamkiewicz G, Hammond SK, et al. Indoor concentrations of nicotine in low-income, multi-unit housing: associations with smoking behaviours and housing characteristics. Tob Control 2009;18:438-44.

39. Dales R, Ruest K, Guay M, et al. Residential fungal growth and incidence of acute respiratory illness during the first two years of life. Environ Res 2010; 110:692-8.

40. Miller JD, Dugandzic R, Frescura A-M, et al. Indoor- and outdoor-derived contaminants in urban and rural homes in Ottawa, Ontario, Canada. J Air Waste Manag Assoc 2007;57:297-302.

41. Salares VR, Hinde CA, Miller JD. Analysis of settled dust in homes and fungal glucan in air particulate collected during HEPA vacuuming. Indoor Built Environ 2009;18:485-91.

42. Dales RE, Miller D. Residential fungal contamination and health: microbial cohabitants as covariates. Environ Health Perspect 1999;107(Suppl 3):481-3.

43. Carter T, editor. Perspectives on Canadian housing policy. Occasional Paper No. 17. Winnipeg: The Institute of Urban Studies; 1989.

44. Carter T. Evolution of Northern housing policy. Northern Studies No. 2. Winnipeg: The Institute of Urban Studies; 1993.

45. Dales R, Miller D, Ruest $\mathrm{K}$, et al. Airborne endotoxin is associated with respiratory illness in the first 2 years of life. Environ Health Perspect 2006;114:610-4.

46. Rylander R. Endotoxin in the environment: exposure and effects. J Endotoxin Res 2002;8:241-52.

47. Park JH, Gold DR, Spiegelman DL, et al. House dust endotoxin and wheeze in the first year of life. Am J Respir Crit Care Med 2001;163:322-8.

48. Perzanowski MS, Miller RL, Thorne PS, et al. Endotoxin in inner-city homes: associations with wheeze and eczema in early childhood. J Allergy Clin Immunol 2006;117:1082-9.

49. Kovesi $\mathrm{T}$, Rowe $\mathrm{BH}$, Majaesic $\mathrm{C}$, et al. Prevalence of asthma and risk factors for asthma-like symptoms in Aboriginal and non-Aboriginal children in the northern territories of Canada. Can Respir J 2008; 15: 139-45. Can Respir J 2008;15:240.

50. Miller DJ, Jiang D, Ruest KL, et al. The impact of wood heating in houses on air borne endotoxin and sustainable heating in rural forested areas. Proceedings of the 12th International Conference on Indoor Air Quality and Climate; 2011 June 5-10; Austin (TX). Red Hook (NY): Curran Associates Inc.; 2011:3042.

51. Iossifova YY, Reponen T, Bernstein DI, et al. House dust (1-3)-beta-D-glucan and wheezing in infants. Allergy 2007;62:504-13.

52. Merckx J, Ducharme FM, Martineau C, et al.; Pediatric Emergency Research Canada (PERC) DOORWAY team. Respiratory viruses and treatment failure in children with asthma exacerbation. Pediatrics 2018;142:e20174105.

53. Maclntyre CR, Chughtai AA, Barnes M, et al. The role of pneumonia and secondary bacterial infection in fatal and serious outcomes of pandemic influenza a(H1N1)pdm09. BMC Infect Dis 2018;18:637.

54. Rennie DC, Karunanayake CP, Lawson JA, et al. Domestic risk factors for atopic and non-atopic asthma in First Nations children Living in Saskatchewan, Canada. Children (Basel) 2020;7:38.

55. Antova T, Pattenden S, Brunekreef B, et al. Exposure to indoor mould and children's respiratory health in the PATY study. J Epidemiol Community Health 2008;62:708-14.

56. Banerji A, Bell A, Mills EL, et al. Lower respiratory tract infections in Inuit infants on Baffin Island. CMAJ 2001;164:1847-50.

57. Nandasena S, Wickremasinghe AR, Sathiakumar N. Indoor air pollution and respiratory health of children in the developing world. World J Clin Pediatr 2013;2:6-15.

58. Noonan CW, Semmens EO, Smith P, et al. Randomized trial of interventions to improve childhood asthma in homes with wood-burning stoves. Environ Health Perspect 2017;125:097010.

59. Wheeler AJ, Gibson MD, MacNeill M, et al. Impacts of air cleaners on indoor air quality in residences impacted by wood smoke. Environ Sci Technol 2014;48: 12157-63. 
60. Allen RW, Carlsten C, Karlen B, et al. An air filter intervention study of endothelial function among healthy adults in a woodsmoke-impacted community. Am J Respir Crit Care Med 2011;183:1222-30.

61. Li JS, Peat JK, Xuan W, et al. Meta-analysis on the association between environmental tobacco smoke (ETS) exposure and the prevalence of lower respiratory tract infection in early childhood. Pediatr Pulmonol 1999; 27:5-13.

62. Noonan CW, Ward TJ, Navidi W, et al.; HEI Health Review Committee. Assessing the impact of a wood stove replacement program on air quality and children's health. Res Rep Health Eff Inst 2011;(162):3-37, discussion 39-47.

63. Koch A, Mølbak K, Homøe P, et al. Risk factors for acute respiratory tract infections in young Greenlandic children. Am J Epidemiol 2003;158:374-84.

64. Wu F, Jacobs D, Mitchell C, et al. Improving indoor environmental quality for public health: impediments and policy recommendations. Environ Health Perspect 2007;115:953-7.

65. Burke T. Carleton helps get the word out in Indigenous communities. Ottawa: Carleton University; 2020. Available: https://newsroom.carleton.ca/story/ indigenous-communities-public-health/ (accessed 2020 May 19).
66. Haines SR, Adams RI, Boor BE, et al. Ten questions concerning the implications of carpet on indoor chemistry and microbiology. Build Environ 2019;170:1-16.

67. Maheswaran D, Zeng Y, Chan-Yeung M, et al. Exposure to Beta-(1,3)-D-glucan in house dust at age 7-10 is associated with airway hyperresponsiveness and atopic asthma by age 11-14. PLoS One 2014;9:e98878.

68. Lawton MD, Dales RE, White J. The influence of house characteristics in a Canadian community on microbiological contamination. Indoor Air 1998;8:2-11.

69. Airaksinen M, Pasanen P, Kurnitski J, et al. Microbial contamination of indoor air due to leakages from crawl space: a field study. Indoor Air 2004;14:55-64.

70. Farha L; Secretary-General UN; UN Human Rights Council. Adequate housing as a component of the right to an adequate standard of living, and the right to non-discrimination in this context: note/by the Secretary-General. United Nations, New York: United Nations; 2019.

71. Ward T, Boulafentis J, Simpson J, et al. Lessons learned from a woodstove changeout on the Nez Perce Reservation. Sci Total Environ 2011;409:664-70.

72. Singleton R, Salkoski AJ, Bulkow L, et al. Impact of home remediation and household education on indoor air quality, respiratory visits and symptoms in Alaska Native children. Int J Circumpolar Health 2018;77:1422669.
Competing interests: Thomas Kovesi reports being a member of the board of governors of the Ontario Lung Association. Dr. Kovesi also reports using equipment from Health Canada for this study, and that sample analysis and data compilation were performed by Health Canada and Environment Canada. Yoko Schreiber reports receiving fees from the Indigenous Services Canada-First Nations and Inuit Health Branch Pharmacy and Therapeutics Committee, and acting as chair of the Indigenous Health Committee, Association of Medical Microbiology and Infectious Diseases Canada (unpaid position). Gail Lawlor reports receiving payment from the study operating grant for time spent in the homes conducting the surveys and setting up the IAQ Testing, as well as reimbursement from the study operating grant for expenses incurred for travel and accommodation in the four First Nations communities. No other competing interests were declared.

This article has been peer reviewed.

Affiliations: Department of Pediatrics (Kovesi), Children's Hospital of Eastern Ontario (CHEO), University of Ottawa; Water and Air Quality Bureau (Mallach, Kulka), Healthy Environments and Consumer Safety Branch, Health Canada, Ottawa, Ont.; Northern Ontario School of Medicine (Schreiber), Sioux Lookout, Ont.; Nishnawbe Aski Nation (McKay), Thunder Bay, Ont.; Energy Matters (Lawlor), Pickering, Ont.; CHEO Research Institute (Barrowman, Tsampalieros), University of Ottawa; School of Public Policy and Administration (Root), Carleton University, Ottawa, Ont.; Sioux Lookout First Nations Health Authority (Root); Sioux Lookout Meno Ya Win Health Centre (Kelly), Sioux Lookout, Ont.; Northern Ontario School of Medicine (Kirlew), Sudbury, Ont.; Department of Chemistry (Miller), Carleton University, Ottawa, Ont.

Contributors: Thomas Kovesi and Gary Mallach contributed to the conception and design of the work; the acquisition, analysis and interpretation of the data; and drafting of the manuscript. Yoko Schreiber and Ryan Kulka contributed to the conception and design of the work, the acquisition of data, and drafting of the manuscript. Michael McKay contributed to the design and interpretation of the work and drafting the manuscript. Gail Lawlor and Len Kelly contributed to the design and interpretation of the work, acquisition of data, and drafting of the manuscript. Nick Barrowman and Anne Tsampalieros contributed to the analysis and interpretation of the work and drafting of the manuscript. Ariel Root contributed to the conception and design of the work and drafting of the manuscript. Michael Kirlew contributed to the conception and design of the work. J. Miller contributed to the conception and design of the work; the analysis and interpretation of the data; and drafting of the manu- script. All of the authors revised the manuscript critically for important intellectual content, gave final approval of the version to be published and agreed to be accountable for all aspects of the work.

Funding: Indigenous Services Canada, Health Canada; Children's Hospital of Eastern Ontario Research Institute.

Data sharing: This data set is not available for sharing. When participants consented to participating in the study, they did not consent to data beyond the research team. Readers are welcome to contact the corresponding author for further clarification.

Acknowledgements: The authors thank Janet Gordon and the Sioux Lookout First Nations Health Authority, Nishnawbe Aski Nation, and the communities, Band Councils and Health Centres of Lac Seul First Nation, Kasabonika Lake First Nation, Sandy Lake First Nation, and Kitchenuhmaykoosib Inninuwug First Nation for their advice and support. The authors thank the Chiefs and members of each community: Chief Derek Maud (Lac Seul), Chief Eno H. Anderson (Kasabonika), Chief Delores Kakegamic (Sandy Lake), Chief Donny Morris (Kitchenuhmaykoosib Inninuwug); Sol Mamawka, Member of Provincial Parliament (Riding of Kiiwetinoong, Legislative Assembly of Ontario); Bruce Fraser (Hazard Identification Division, Health Canada); and Constantine Tikhonov (Indigenous Services Canada) for their wisdom and support. The authors acknowledge the kind support of Ewa Dabek-Zlotorzynska (Analysis and Air Quality Section, Air Quality Research Division, Atmospheric Science and Technology Directorate, Science and Technology Branch, Environment Canada). The authors recognize Tim Shin (Air Pollution Exposure Science Section, Health Canada) for assistance with compiling the exposure data set. Finally, the authors thank the Community Health Representatives and families who participated in this study. Written permission to identify the study communities in publications was provided by the Chief of each community.

Content licence: This is an Open Access article distributed in accordance with the terms of the Creative Commons Attribution (CC BY-NC-ND 4.0) licence, which permits use, distribution and reproduction in any medium, provided that the original publication is properly cited, the use is noncommercial (i.e., research or educational use), and no modifications or adaptations are made. See: https://creativecommons.org/licenses/ by-nc-nd/4.0/

Accepted: Dec. 10, 2021

Correspondence to: Thomas Kovesi, kovesi@cheo.on.ca 